\title{
Unexpected cause of respiratory distress
}

\author{
Joana Sotto Mayor, Ana Lages, Sofia Esperança, Antonio Oliveira e Silva
}

Department of Internal Medicine, Hospital de Braga, Braga, Portugal

\section{Correspondence to} Dr Joana Sotto Mayor s.mayor.joana@gmail.com

Accepted 8 December 2015

\section{DESCRIPTION}

An 80-year-old woman with a history of pyrosis, chronic obstructive pulmonary disease (diagnosis details unknown) and dementia syndrome, presented to the emergency room after 4 days of productive cough with mucopurulent sputum and progressive worsening dyspnoea. There was no history of trauma. On physical examination, she was depressed with signs of respiratory distress. There were no alterations in heart auscultation and lung auscultation revealed overall decreased breathing sounds, fine bibasilar crackles and scattered ronch. Blood tests showed C reactive protein $26 \mathrm{mg} / \mathrm{dL}$ and leucocytes $9700 \mu \mathrm{L}$. Arterial blood gas analysis at $\mathrm{FiO}_{2} 21 \%$ showed hypoxaemia with hypercapnia. There were no alterations in ECG; chest X-ray was remarkable for extreme enlargement of the mediastinum, with increased density in the lower $2 / 3$ of the lung parenchyma associated with obliteration of the costophrenic angle bilaterally (figure 1). To clarify these findings, a thoracic CT scan was performed, revealing 'dilation of the esophagus and large hiatal hernia with content composed of stomach and transverse colon' (figure 2) without other significant changes. Bowel obstruction was ruled out.

Despite the clinical and X-ray suggesting the presence of cardiac failure, the absence of changes on ECG, and normal heart auscultation, made us question this diagnosis.

This case is relevant for the potential of a voluminous hernia to exacerbate respiratory symptoms in a patient with chronic respiratory disease in her medical history. Since this diagnosis was made in the presence of an acute exacerbation of her

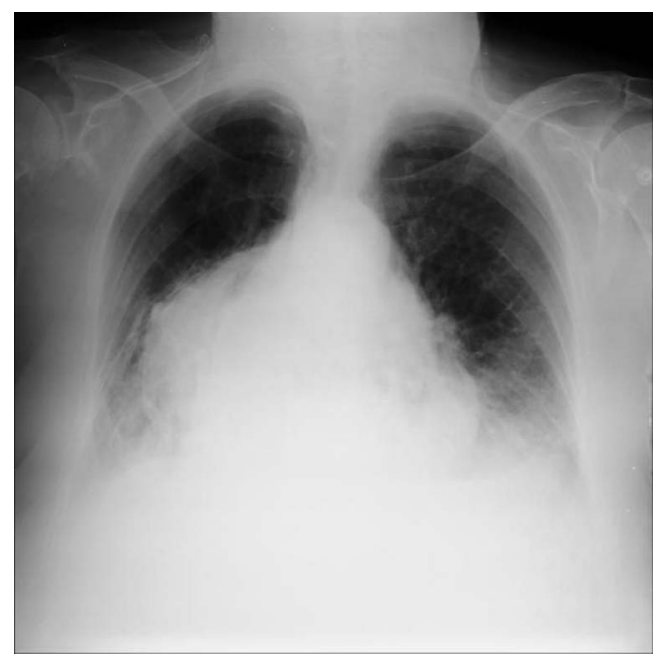

Figure 1 Chest X-ray revealing extreme enlargement of the mediastinum.

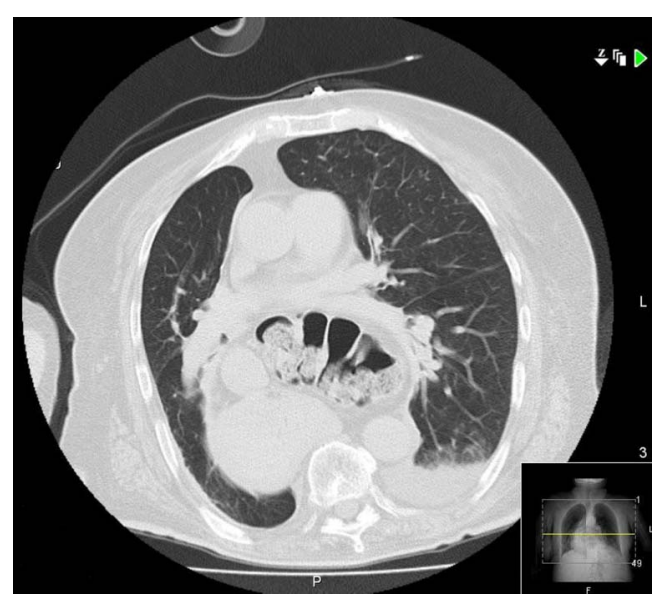

Figure 2 Thoracic CT scan revealing dilation of the esophagus and large hiatal hernia with content composed of stomach and transverse colon.

respiratory disease, increasing surgical risk, treatment of the hiatal hernia had to be postponed. Of note, this patient also had a significant history of gastroesophageal reflux disease-if this had been investigated in a timely manner, we may not have been faced by a patient in such an extreme condition.

\section{Learning points}

- The relevance of this case relates primarily to the importance of valuing the clinical symptoms of patients. In this case, if, at the beginning of her difficulty breathing, the patient's symptoms had been further clinically investigated, then the hernia reaching a critical level with its extreme dimensions compromising the ventilation of the patient could possibly have been avoided.

- Is also important to point out that dyspnoea is not the same as chronic respiratory disease.

- Presence of heartburn, particularly in old age, should always be investigated, because it can be caused by gastroesophageal reflux disease or presence of an esophageal hernia.

Competing interests None declared.

Patient consent Obtained.

Provenance and peer review Not commissioned; externally peer reviewed. 
Copyright 2015 BMJ Publishing Group. All rights reserved. For permission to reuse any of this content visit http://group.bmj.com/group/rights-licensing/permissions.

BMJ Case Report Fellows may re-use this article for personal use and teaching without any further permission.

Become a Fellow of BMJ Case Reports today and you can:

- Submit as many cases as you like

- Enjoy fast sympathetic peer review and rapid publication of accepted articles

- Access all the published articles

- Re-use any of the published material for personal use and teaching without further permission

For information on Institutional Fellowships contact consortiasales@bmjgroup.com

Visit casereports.bmj.com for more articles like this and to become a Fellow 